\title{
QUALITY ASSESSMENT OF HEALTH SERVICES PROVISION OF BASIC HEALTH UNITS OF DISTRICT PESHAWAR
}

\author{
Adeela Mustafa1, Romana Ayub1, Bakht Danyal Khan², Alveena Karam², Faizan², Nayab Ahsan² \\ ${ }^{1}$ Department of Community Medicine, Khyber Medical College, Peshawar - Pakistan \\ ${ }^{2}$ Final Year Medical Students, Khyber Medical College, Peshawar - Pakistan
}

\begin{abstract}
Objective: To assess the quality of services provision of different Basic Health Units of district Peshawar.

Material and Methods: It was a cross-sectional descriptive study that was carried out in 08 Basic health units (BHU) of district Peshawar using convenient sampling technique. Data was collected through a semi structured questionnaire, which was developed and validated in the department of Public Health, Khyber Medical College Peshawar before the start of research. The data collection through field visits continued for about 03 months. The results were analyzed through SPSS version 22.
\end{abstract}

Results: The study was designed in the department of Public health and after approval from ethical board of Khyber Medical College, a questionnaire (having 15 items) for data collection was developed and validated with the help of subject experts. A total of 8 BHUs were selected in the outskirts of Peshawar. Questionnaire were distributed among 100 patients or their accompanying persons. Amongst them, 55 were female patients. The educational status of all of them was below 5 th grade. Quality of BHU was assessed in three domains which were staff attitude, availability of essential drugs and facilities available in BHUs. For staff attitude Likert scale was used and $89 \%$ of Patients were satisfied with the attitude of staff. When asked about availability of essential drugs, $67 \%$ patients said that they do not receive any medicines. When asked about availability of facilities, $75 \%$ of patients said that there is supply of clean drinking water at $\mathrm{BHU}, 50 \%$ of patients said that there was no electricity during their stay at BHU. Regarding availability of doctors, $63 \%$ claimed that doctor was present during their visit. About $92 \%$ of patients said that $\mathrm{BHU}$ is easily accessible. However, $91 \%$ agreed that there is still room for improvement.

Conclusion: It is concluded from this study that most of Basic health units are accessible to the users and they are satisfied with the attitude of staff but all of BHUs had problem of essential drugs availability.

Key words: BHU, quality assessment, service provisionr

This article may be cited as: Mustafa A, Ayub R, Khan BD, Karam A, Faizan, Ahsan N. Quality Assessment of Health Services Provision of Basic Health units of district Peshawar. J Med Sci 2020 October;28(4):377-379

\section{INTRODUCTION}

The role of BHUs in treating common diseases among local population cannot be ignored. BHUs are the first level care facilities to provide healthcare to local communities. Pakistan having population of more than 200 million people has extensive network of BHUs. ${ }^{1,2,3}$ Pakistan is a nation that has made progress towards economic development but is struggling towards sustainable development. Most of these BHUs have not been fully utilized with average number of only 10 to 20 patient reporting per day due to reasons like administrative, infrastructure problems, non-availability of medicine, ${ }^{4-6}$ problems with attitudes of health professionals and inaccessible locations. ${ }^{7,8}$ Health system now focuses on their primary health

\section{Correspondence}

Dr. Adeela Mustafa

Department of Community Medicine, Khyber Medical

College, Peshawar - Pakistan

Email: adeelaamir17@gmail.com

Cell: +92-345-2909019

Date received: $31-05-2020$

Date revised: $\quad 08-06-2020$

Date accepted: $15-12-2020$ services through clinical and financial aspects to get better results and in turn whole health system becomes sustainable. ${ }^{10}$ For provision of high quality of primary health care services there is a dire need to develop methods for quality assessment and monitoring system. ${ }^{11}$ Physical structure of these centers should incorporate availability of all required equipment and continuous supply of drugs to meet needs of population. In addition to this, availability of staff and their behavior is also important to strengthen the role of these facilities in provision of health services. ${ }^{12}$ China has made large investment in health by upgrading its primary health care level by making it more affordable, accessible and according to needs of people. Patient's experience at health facility is major determinant of trust and satisfaction with services provided. Countries having strong primary health care system have reduced morbidity, increased longevity of people and increased equity in health outcomes. ${ }^{13}$

This study is aimed to assess the service provisions of Basic health units of Peshawar district. This will improve our understanding about the service provision in these facilities and will alert the governmental agencies 
Quality Assessment Of Health Services Provision Of Basic Health Units Of District Peshawar.

about the deficiencies identified.

\section{MATERIAL AND METHODS}

A cross-sectional descriptive study was carried out to assess the quality of $08 \mathrm{BHUs}$ out of total $25 \mathrm{BHUs}$ of district Peshawar, BHUs were selected through convenient sampling technique in outskirts of Peshawar. A total of 100 respondents participated in the study and data was collected during a period of three months. A thorough analysis of BHUs was done in three domains which were staff attitude, availability of essential drugs and facilities available at these health centers. Likert scale was used to assess these domains and questionnaire was filled by patients or their attendants in the presence of $4^{\text {th }}$ year MBBS students. Statistical analysis was performed using SPSS version 22. $P$ value of less than 0.05 was considered significant. The research process was approved by Research Ethics Committee of KMC.

\section{RESULTS}

Regarding availability of water, $75 \%$ of the patients said that clean drinking water was available during their stay at health unit, while $50 \%$ of patients said that there was no electricity at $\mathrm{BHU}$ during their visit. The number of patients per day was calculated (during working hours from 8 am to $2 \mathrm{pm}$ ) after consulting the respondents and by taking record of medical registers and average number of patients was 15 to 20 per day. Regarding the staff, results were mostly positive with $90 \%$ of respondents claiming that their appointment was on time and $89 \%$ claiming that the staff was cordial and welcoming. seventy Six Percent of patients were satisfied with the care they received at health unit. When asked about availability of medicines, $65 \%$ claimed that they did not receive any medicines. According to $92 \%$ of patients, $\mathrm{BHU}$ was accessible to them.

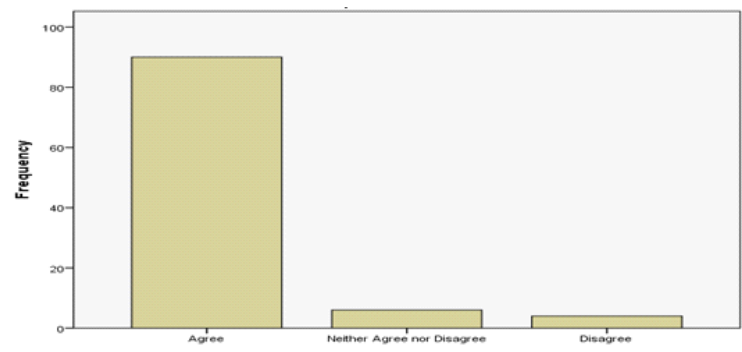

Fig 1: Views about cooperation of staff

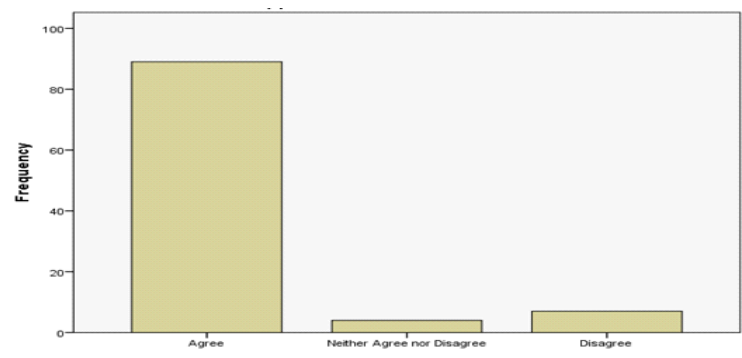

Fig 2: Views about timely appointment
Table 1: Number of Patients satisfied with care

\begin{tabular}{|c|c|c|}
\hline Response & Frequency & Percent \\
\hline Yes & 76 & 76.0 \\
\hline No & 24 & 24.0 \\
\hline Total & 100 & 100.0 \\
\hline
\end{tabular}

Table 2: Availability of medicines

\begin{tabular}{|c|c|c|}
\hline Response & Frequency & Percent \\
\hline Yes & 33 & 33.0 \\
\hline No & 67 & 67.0 \\
\hline Total & 100 & 100.0 \\
\hline
\end{tabular}

Table 3: Accessibility of BHU

\begin{tabular}{|c|c|c|}
\hline Response & Frequency & Percent \\
\hline Yes & 92 & 92.0 \\
\hline No & 08 & 8.0 \\
\hline Total & 100 & 100.0 \\
\hline
\end{tabular}

\section{DISCUSSION}

In Pakistan infrastructure of Basic health units is in good condition but services are not provided according to the needs of people. In a previous study conducted in Pakistan, to assess the infrastructure of BHUs, it was found that out of $992 \mathrm{BHUs}$ of country, $67 \%$ were in better condition out of which $89 \%$ were in Punjab, 64\% in KPK to $15 \%$ in Baluchistan. ${ }^{14}$ While in this study most of facilities were available in BHUs except for essential drugs. When compared with primary healthcare system of India, where manpower is found deficient to cater the large population of India. ${ }^{15,16}$ The Primary health care structure of India was found to be rigid, making it unable to respond effectively to the needs of people. Patients also complained about rude behavior of medical staff towards female patients and minorities. ${ }^{17}$

In the UK, unlike many other countries, there is continuous supply of water and electricity and very well-maintained buildings but patient do not normally have direct access to hospital consultant and GP, controls access to secondary care. ${ }^{18}$ These finding are contrary to our study, where there is easy access to health care facility and availability of water. In a study conducted in Nigeria, there was lack of infrastructure, non-availability of essential drugs at primary health care level and only $20 \%$ of facilities had minimum equipment. These findings are somewhat similar to our study. ${ }^{19}$

When compared with Iran, where more than $90 \%$ of the population has health insurance and the government has made universal health coverage by 2018 , a priority but shortage of medicines and trained staff is also a problem in rural health centers of Iran. ${ }^{20}$

One of the important limitations of this study is its contextual nature, as it includes only localities of Pesha- 
war, which limits its generalizations. However it is a good start in evaluating the basic health system of the province.

\section{CONCLUSION}

This study concludes that most of Basic health units are accessible to the users and they are satisfied with the attitude of staff, as most of staff is welcoming but the main problem found in all of BHUs is the availability of essential drugs. Due to this reason number of patients visiting these health facilities are also scarce.

\section{REFERENCES}

1. Nishtar S, Bhutta ZA, Jafar TH, Ghaffar A, Akhtar T, Bengali K, Isa QA, Rahim E. Health reform in Pakistan: The Lancet.2013;29-381

2. Kurji Z, Premani ZS, Mithani Y. Analysis of the health care system of Pakistan: lessons learnt and way forward. J Ayub Med Coll Abbottabad. 2016;28(3):601.

3. Malik MA, Iqbal SP, Abrejo F. Nature, scope and use of economic evaluation of healthcare programmes: with special reference to Pakistan. JPMA. The Journal of the Pakistan Medical Association. 2017;67(5):773.

4. Usman A, Alina BA, Amjad A, Amjad U. Reformative measures for basic health units in Pakistan. Iranian journal of public health. 2015 Oct 11;44(8):1158-9.

5. Punjani NS, Shams S, Bhanji SM. Analysis of health care delivery systems: pakistan versus united states. Int J Endorsing Health Sci Res. 2014;2(1):38-41.

6. Akram M, Khan FJ. Health care services and government spending in Pakistan. Working Papers \& Research Reports:2007

7. Papp SA, Gogoi A, Campbell C. Improving maternal health through social accountability: A case study from Orissa, India. Global public health. 2013 ;8(4):449-64

8. Usman A, Alina BA, Amjad A, Amjad U. Reformative measures for basic health units in Pakistan. Iranian journal of public health. 2015 Oct 11;44(8):1158-9.

9. Tang S, Brixi H, Bekedam H. Advancing universal coverage of healthcare in China: translating political will into policy and practice. The International journal of health planning and management. 2014 Apr;29(2):160-74.

10. Afzal U, Yusuf A. The state of health in Pakistan: An overview. InThe State of Health in Pakistan: An Overview" with Anam Yusuf, paper presented at the Ninth Annual Conference on Management of the Pakistan Economy, Lahore School of Economics;2013:233-247

11. Mankuta D, Vinker S, Itzhak B, Kaiserman I, Beiran I. A quality management project in israeli navy primary care clinics. American Journal of Medical Quality. 1999 ;14(5):211-5.

12. Starfield B, Shi L, Macinko J. Contribution of primary care to health systems and health. The milbank quarterly. 2005 Sep;83(3):457-502.
13. Jamison DT, Summers LH, Alleyne G, Arrow KJ, Berkley S, Binagwaho A, Bustreo F, Evans D, Feachem RG, Frenk J, Ghosh G. Global health 2035: a world converging within a generation. The Lancet. 2013 Dec 7;382(9908):1898955.

14. Moreira KS, Lima CA, Vieira MA, Costa SM. Assessment of infrastructure of family health units and equipment used in primary care actions. Cogitare Enferm. 2017;22(2):e51283.

15. Majrooh MA, Hasnain S, Akram J, Siddiqui A. A cross-sectional assessment of primary healthcare facilities for provision of antenatal care: calling for improvements in Basic Health Units in Punjab, Pakistan. Health research policy and systems. 2015 Dec 1;13(S1):S59.

16. Harshal Tukaram Pandve,Tukaram K Pandave.Primary Health care system in India:Evaluation and Challenges.2013;1(3):125-128

17. Beaglehole R, Epping-Jordan J, Patel V, Chopra M, Ebrahim S, Kidd M, Haines A. Improving the prevention and management of chronic disease in low-income and middle-income countries: a priority for primary health care. The Lancet. 2008 Sep 13;372(9642):940-9

18. Kumar V,Mishra AJ.Quality of health care in primary health care system:A reflection from Indian state.Int $\mathrm{J}$ Health Syst Disaster Management 2015;3:136-40

19. Messerli P, Murniningtyas E, Eloundou-Enyegue P, Foli EG, Furman E, Glassman A, Hernández Licona G, Kim EM, Lutz . Global Sustainable Development Report 2019: The Future Is Now-Science for Achieving Sustainable Development.

20. Ghaljeh M, Iranmanesh S, Nayeri ND, Tirgari B. Organizational challenges: A major obstacle at end of life care in Iran. Journal of Advances in Medicine and Medical Research. 2016 Jun 28:1-2.

CONFLICT OF INTEREST: Authors declare no conflict of interest

GRANT SUPPORT AND FINANCIAL DISCLOSURE: NIL

\section{AUTHOR'S CONTRIBUTION}

Following authors have made substantial contributions to the manuscript as under

Mustafa A: Concept, Design, Review

Ayub R: $\quad$ Concept, Design, Review

Khan BD: Data Collection, Manuscript writing

Karam A: $\quad$ Data Collection, Manuscript writing

Faizan: Data Collection, Manuscript writing

Ahsan N: $\quad$ Data Collection, Manuscript writing

Authors agree to be accountable for all aspects of the work in ensuring that questions related to the accuracy or integrity of any part of the work are appropriately investigated and resolved. 